\title{
An important step towards a prevascularized islet microencapsulation device: in vivo prevascularization by combination of mesenchymal stem cells on micropatterned membranes
}

\author{
Maria Chatzinikolaidou, Aldo R. Boccaccini
}

\begin{abstract}
Milou Groot Nibbelink ${ }^{1} \cdot$ Katarzyna Skrzypek ${ }^{2} \cdot$ Lisanne Karbaat $^{2} \cdot$ Sanne Both $^{1} \cdot$ Jacqueline Plass $^{1}$. Bettie Klomphaar ${ }^{3} \cdot$ Jéré van Lente $^{1} \cdot$ Sieger Henke ${ }^{1} \cdot$ Marcel Karperien $^{1} \cdot$ Dimitrios Stamatialis $^{2}$. Aart van Apeldoorn ${ }^{1,4}$
\end{abstract}

Received: 30 November 2017 / Accepted: 17 October 2018 / Published online: 9 November 2018

(c) The Author(s) 2018

\begin{abstract}
Extrahepatic transplantation of islets of Langerhans could aid in better survival of islets after transplantation. When islets are transfused into the liver 60-70\% of them are lost immediately after transplantation. An important factor for a successful extrahepatic transplantation is a well-vascularized tissue surrounding the implant. There are many strategies known for enhancing vessel formation such as adding cells with endothelial potential, the combination with angiogenic factors and / or applying surface topography at the exposed surface of the device. Previously we developed porous, micropatterned membranes which can be applied as a lid for an islet encapsulation device and we showed that the surface topography induces human umbilical vein endothelial cell (HUVEC) alignment and interconnection. This was achieved without the addition of hydrogels, often used in angiogenesis assays. In this work, we went one step further towards clinical implementation of the device by combining this micropatterned lid with Mesenchymal Stem Cells (MSCs) to facilitate prevascularization in vivo. As for HUVECs, the micropatterned membranes induced MSC alignment and organization in vitro, an important contributor to vessel formation, whereas in vivo (subcutaneous rat model) they contributed to improved implant prevascularization. In fact, the combination of MSCs seeded on the micropatterned membrane induced the highest vessel formation score in $80 \%$ of the sections.
\end{abstract}

\section{Graphical Abstract}

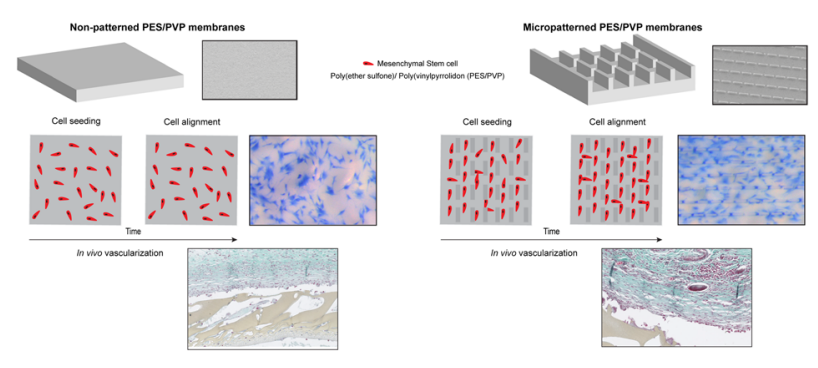

Electronic supplementary material The online version of this article (https://doi.org/10.1007/s10856-018-6178-6) contains supplementary material, which is available to authorized users.

Milou Groot Nibbelink

m.grootnibbelink@utwente.nl

Extended author information available on the last page of the article

\section{Introduction}

Type 1 Diabetes mellitus is a chronic disease that manifests in children and young people (usually $<30$ years). An autoimmune reaction destructs the insulin producing $\beta$ cells resulting in hyperglyceamia as well as relative insulin deficiency [1-5]. Diabetes Type I is known for its severe 
acute and long-term complications due to micro- and macroangiopathic lesions and has a significant social and economic impact. Long term symptoms are retinopathy, neuropathy, and nephropathy [4, 6-12].

Due to the inadequate produced insulin, type 1 Diabetes mellitus patients need life-long insulin therapy and tight glucose monitoring. Patients with severe glyceamic lability, recurrent hypoglycaemia, hypoglycaemia unawareness, or an insufficient response to the insulin therapy are in need for alternative therapies. Current alternative treatments are total pancreas transplantation or clinical islet transplantation [4, $7,8,11,12]$. Both alternatives have the disadvantage of limited donor availability and a need for life-long immunosuppressive drugs as both the pancreas and islets are of allogeneic origin. The advantages of islet transplantation over whole pancreas transplantation are the lower surgical risk and fewer complications [8].

In CIT $60-70 \%$ of the donor islets of Langerhans are lost immediately after transplantation. This is due to many different factors including mechanical stress, different immune-responses, and lack of vascularization. In fact, after intraportal infusion, islets are immediately exposed to high concentrations of drugs and nutrients, such as glucose, which negatively affects their function [13-20]. Additionally, the islets are in a pro-inflammatory state at the moment of transplantation due to the isolation procedure, therefore, they express inflammatory mediators, leading to the onset of different immune-responses, like Instant Blood Mediated Immune Response (IBMIR) and alloresponse which in the end leads to graft failure [21].

Previous research has focused on improving the transplantation outcome by immune-protective strategies that prevent immune cells from reaching encapsulated islets while maintaining islet viability. Good examples of this are membrane based scaffolds as they could maintain islet viability and act as a physical barrier for the immune system. These scaffolds should meet stringent requirements: islets need to be separated from the blood stream, the device needs to be permeable for glucose, insulin, nutrients, and oxygen, and the device needs to be impermeable to the immune cells [7, 14, 22-26].

One of the key issues related to the development of an immune protective scaffold for extrahepatic islet transplantation is the scaffold prevascularization or the enhanced vascularization directly after implantation. It is actually important to provide blood supply close to the islets since the isolation process disrupts their own vasculature whereas the islets are normally highly vascularized in the pancreas. In fact, islets receive $5-15 \%$ of the total blood supply of the pancreas while they only consist of $1 \%$ of the entire pancreas mass $[6,27,28]$. It is known that hypoxia leads to a loss of viability and glucose responsiveness. Neoangiogenesis will allow perfusion of islets, however, this generally only starts approximately 7 days post transplantation. It is obvious that enhancing vascularization around the implant would be critical to optimal islet survival and function [7, 13-15, 22, 29].

Improved implant vascularization would also reduce the inflammatory response during first post-transplantation period. Due to better vascularization, higher oxygen supply will be available thereby reducing hypoxia in islets. Normally, hypoxia results in islet ischemia followed by the production of reactive oxygen species (ROS). Resulting in an activated inflammatory pathway NF-kB $[13,30]$.

There are many different ways to enhance vascularization of the encapsulated islets, either by prevascularization of the device or by induction of vascularization in vivo [28, 31]. This can be achieved by the release of angiogenic factors by drugs or cells. Materials with specific surface topographies can also enhance blood vessel formation and reduce the immune response that is responsible for the formation of the fibrous capsule [26, 32]. Already in 1990's, Baxter Healthcare discovered that biomaterial topography could positively influence vessel formation [32]. Moreover, when designing surface topographies for vessel formation, an important factor would be the induction of cell alignment, as it has been shown that cell alignment induces vascularization [33].

Moreover, the islet implant vascularization could also be improved by culturing cells with endothelial potential, like mesenchymal stromal cells (MSCs), fibroblasts, endothelial (progenitor) cells, and bone marrow progenitor cells. This can be achieved by either seeding cells directly on the scaffold or by coating the islets with cells [26, 34-41]. Besides, the MSCs do not only contribute to the induction of vessel formation, but they could also reduce the immune response against the encapsulated islets. Therefore, autologous MSCs, derived from a bone marrow aspirate taken from the patient may offer a big advantage for clinical islet transplantation [42-46].

In our recent work, we showed the development of an encapsulation device for islets of Langerhans. The device consisted of a microwell poly (ether sulfone)/polyvinyl pyrrolidone (PES/PVP) membrane for islet separation covered by a membrane lid. Both membranes were porous to allow nutrients, glucose, and insulin to diffuse through [47]. In a recent study, we also reported that a micropatterned lid can induce alignment of human umbilical vein endothelial cells (HUVEC) [48]. In fact, a surface topography of an intermittent brick pattern there allowed for communication between cells and the connection of HUVEC branch-like structures creating a network over the membrane surface (Fig. 1). This was achieved by co-culture of HUVECs on the monolayer of fibroblasts without the addition of hydrogels. There, we coated the membrane lid with fibronectin but we did not use angiogenic gels since those could block the membrane pores limiting the transport properties 


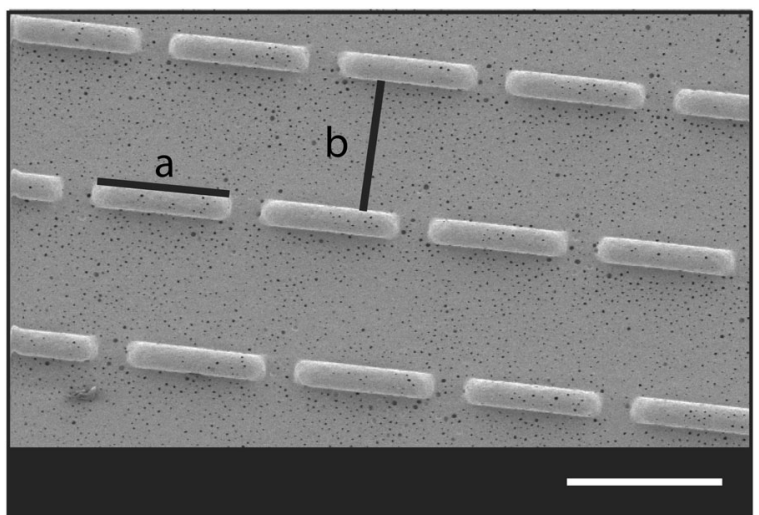

Fig. 1 Micropatterns porous membrane with brick like surface topographies. The bricks have height of $40 \mu \mathrm{m}$ and length of $100 \mu \mathrm{m}$ a. The spacing between the bricks pattern is $100 \mu \mathrm{m} \mathbf{b}$

of the implant. The distance between the patterns was 100 $\mu \mathrm{m}$, since it has been shown that cell alignment occurs in patterns between 20-130 $\mathrm{m}$ [49]. These results were in accordance with literature where it has been shown that HUVEC alignment can be tailored using micropatterns [50-52].

In this work, we investigate whether these micropatterned membranes with brick like surface topography could also induce MSC organization in vivo. Cell attachment to the membrane was achieved using a fibronectin coating and the membranes were implanted subcutaneously in a rat model. To the best of our knowledge, this study is the first that investigates the combined effect of micropatterned membranes and MSCs for inducing vascularization of an implant device without the addition of hydrogels or angiogenic factors.

\section{Materials and Methods}

\subsection{Membrane fabrication}

A $15 \mathrm{wt} \%$ poly(ether sulfone) (PES) (Ultrason, the Netherlands) 5 wt\% poly-(vinylpyrrolidon) (PVP) (SigmaAldrich) polymer solution in N-methylpyrrolidone (NMP) (Sigma-Aldrich) was used to cast membranes as described by Skrzypek et al. [48]. In short: The membranes were cast on a glass plate (for non-patterned membranes) or on a micropatterend silicon wafer for the brick like surface topography. The micropatterns were $40 \mu \mathrm{m}$ in height and $100 \mu \mathrm{m}$ apart and the bricks had a length of $100 \mu \mathrm{m}$ (Fig. 1). When, directly after casting, the polymer was submerged in a water coagulation bath, phase separation occurred and porous membranes were formed. Finally, all the membranes were rinsed with demineralized water to remove remaining solvent traces and stored in demineralized water till further use.

\subsection{Animal housing and cell culture}

The ethical committee of the University Medical Center Utrecht approved the animal experiments. The care and operative procedure of the rats were performed following the regulation of the central laboratory animal institute in Utrecht. All animal studies were performed at the University of Twente. Rat bone marrow derived MSCs were harvested from two 10-11-week-old female Lewis rats (Harlan, the Netherlands). Rats were euthanized with $\mathrm{CO}_{2}$, shaved, and the skin was sterilized using $70 \%$ ethanol. Both femurs were resected and placed in sterile PBS with $200 \mathrm{U} / \mathrm{mL}$ Penicillin and $200 \mathrm{mg} / \mathrm{mL}$ Streptomycin (Gibco) for at least $15 \mathrm{~min}$ The epiphysis was cut off and the femur was flushed with Minimum Essential Medium $\alpha$ ( $\alpha$-MEM, Life Technologies) with $2 \mathrm{mM}$ GlutaMAX, $100 \mathrm{mU} / \mathrm{mL}$ penicillin and $1 \mathrm{mg} / \mathrm{mL}$ streptomycin (Gibco), and $0.2 \mathrm{mM}$ L-ascorbic acid-2-phosphate (ASAP) using a $22 \mathrm{G}$ needle and syringe. The cell suspension per femur was plated in 1 flask. FBS was added to the cell suspension with a final concentration of $10 \%$. After three days, the medium was refreshed. MSCs were grown to $80 \%$ confluence using Minimum Essential Medium $\alpha$ ( $\alpha$-MEM, Life Technologies) with 10\% FBS, 2 $\mathrm{mM}$ GlutaMAX, $100 \mathrm{mU} / \mathrm{mL}$ penicillin and $1 \mathrm{mg} / \mathrm{mL}$ streptomycin (Gibco), and $0.2 \mathrm{mM} \mathrm{L-ascorbic} \mathrm{acid-2-}$ phosphate (ASAP).

\subsection{Coating of membranes}

The porous membrane was coated with fibronectin (Sanquin, Amsterdam) to enable cell attachment, as described elsewhere [48]. A fibronectin solution of $200 \mu \mathrm{g} / \mathrm{ml}$ was prepared in PBS. The solution was poured on the membranes and incubated for $30 \mathrm{~min}$ at $37^{\circ} \mathrm{C}$. After this, the membranes were incubated with culture medium for $1 \mathrm{~h}$, after which cells were seeded on top.

\subsection{Cell attachment on membranes}

MSC attachment on flat porous PES/PVP membranes uncoated or coated with fibronectin $(200 \mu \mathrm{g} / \mathrm{mL})$ was assessed, as described in Skrzypek et al. [48]. In short: MSCs were seeded with a density of 10.000 cells $/ \mathrm{cm}^{2}$ and kept in culture for 1 day. Subsequently, samples were fixed in $10 \%$ buffered formalin for 10 min Subsequently, samples were fixed in $10 \%$ buffered formalin for $10 \mathrm{~min}$ After fixation samples were washed in $\mathrm{dH} 2 \mathrm{O}(2 \mathrm{x})$ and stained with methylene blue (Sigma-Aldrich) for $10 \mathrm{sec}$. followed by a $3 \mathrm{x}$ wash with $\mathrm{dH} 2 \mathrm{O}$. Quantification of the number of cells on the membranes was done by taking 3 pictures of each membrane and counting the number of cells (Nikon SMZ800 microscope). 


\subsection{Cell alignment on micropatterned membranes}

MSCs were seeded on micropatterned membranes to assess cell alignment following the surface topography $(n=3)$. Similar to the cell attachment experiments, the cells were seeded on $200 \mu \mathrm{g} / \mathrm{mL}$ fibronectin coated membranes $\left(10.000 \mathrm{cells} / \mathrm{cm}^{2}\right)$. After 7 days, the samples were fixed in $10 \%$ formalin for $10 \mathrm{~min}$ and stained using DAPI (Invitrogen, 1:100). Images were taken using a BDpathway 435 microscope and analyzed using CellProfiler (v 2.1.1). The orientation of the cell nucleus was estimated as: the angle between the $\mathrm{x}$-axis (aligned with the image) and the major axis of the ellipse of the nuclei.

\subsection{Micropatterned membranes and MSCs for in vivo vascularization in female Lewis rats}

In vivo vascularization of the micropatterned membranes and the addition of MSCs were tested by subcutaneous implantation in female Lewis rats. In short; non-patterned and patterned PES/PVP membranes $\left(0.79 \mathrm{~cm}^{2}\right)$ were sterilized in $70 \%$ ethanol, washed in PBS and coated with 200 $\mu \mathrm{g} / \mathrm{mL}$ fibronectin. MSCs isolated from female Lewis rats were seeded on the membranes (Pooled from 4 femurs, Passage 2, 3.000 cells $/ \mathrm{cm}^{2}$ ). After 4 days of culture membranes were ready for implantation. Control membranes were fixed and stained for methylene blue to confirm the presence of a monolayer upon implantation. Eleven to twelve -week-old female Lewis rats $(n=6)$ (Harlan, the Netherlands), were injected subcutaneously with Carprofen $(5 \mathrm{mg} / \mathrm{kg}$ ) $30 \mathrm{~min}$ before surgery. Then, they were anesthetized using isoflurane, their back was shaved and sterilized using 70\% ethanol and Betadine. During the entire surgery, their temperature was monitored rectally. Six subcutaneous pockets were created on the back of each rat. In each pocket, a membrane was implanted. Each condition was implanted in each rat in a randomized order to correct for a possible influence of location. The incisions were first closed intracutaneously and finally the skin was sutured. After 14 days, the rats were euthanized with $\mathrm{CO}_{2}$, samples were explanted, fixed in $4 \%$ buffered paraformaldehyde (ON, $4{ }^{\circ} \mathrm{C}$, Sigma Aldrich), and processed for immunehistochemistry. From each sample three locations with at least $125 \mu \mathrm{m}$ between the samples were used for analysis. Sections were stained for Toluidine Blue to detect mast cells. In short Toluidine blue (Sigma Aldrich) was dissolved in $70 \%$ ethanol. At the day of staining, the stock solution was $10 \mathrm{x}$ diluted in $1 \%$ sodium chloride, after which the $\mathrm{pH}$ was set at 2.3. Deparaffinized and hydrated sections were stained with the working solution for 3 min Finally, the samples were dehydrated, cleared with xylene and mounted in Tissue Tex. A Masson Goldner Trichrome staining was performed to detect vessels using the manufacture's protocol (Merck Chemicals, Darmstadt, Germany). Stained microscopy slides were scanned using a Nanozoomer slide scanner 2.0 RS (Hamamatsu, Hamamatsu City, Japan). Trichrome stained sections from day 14 samples (with a folded configuration upon explantation) were scored by three blinded individuals, independently to assess the extent of vessel formation. Sections were scored with - (no blood vessels), + (1-2 blood vessels), or $++(>3$ blood vessels $)$ for vessel formation around the implant.

\subsection{Statistical analysis}

To determine the effect of fibronectin concentration on cell attachment the following analysis was performed. From each sample three pictures were taken, since all used cell types have the tendency to grow in clusters after initial attachment, pictures were taken of the densest, least dense and average covered areas. Average cell numbers on $1 \mathrm{~mm}^{2}$ were determined for each sample. Statistical differences in cell numbers between the conditions and control were determined by a Welch t-test $(\mathrm{P}<0.05=*, \mathrm{P}<0.01=* *$ and $\mathrm{P}<0.001=* * *)$. Fleiss'kappa was used to establish agreement between the three observers of the Trichrome staining. The overall obtained kappa was 0.32 (fair agreement) and there was a moderate agreement $(\kappa=0.63)$ for the ++ classification.

\section{Results}

\subsection{Attachment and alignment of MSCs to PES/PVP porous membranes}

The PES/PVP membranes have low cell adhesion properties. In fact, the combination of the hydrophobic PES with the hydrophilic PVP is ideal to minimize the protein adhesion and thereby cell adhesion. Therefore, PES/PVP is the main biomaterial for the fabrication on membranes for blood filtration where low cell adherence and fouling is required [53]. Previously, we found that a fibronectin coating could achieve good adhesion of fibroblasts and HUVECs on the micropatterned PES/PVP membranes, which is in accordance to other studies $[48,54,55]$. Here, we show, in agreement with Skrzypek et al. [48]. that 200 $\mu \mathrm{g} / \mathrm{mL}$ fibronectin coating also improved the attachment of MSCs to PES/PVP membranes (Fig. 2a). Besides, as alignment, spreading and organization of cells increases vessel formation [33], we assessed whether the MSCs would then align to the micropatterns. Fig. $2 b$ shows cell spreading on the PES/PVP membranes. MSCs spread over the surface of both, pattern and non-pattern membrane. Additionally, in case of cells cultured on patterned membranes it was observed that cells spread following the 

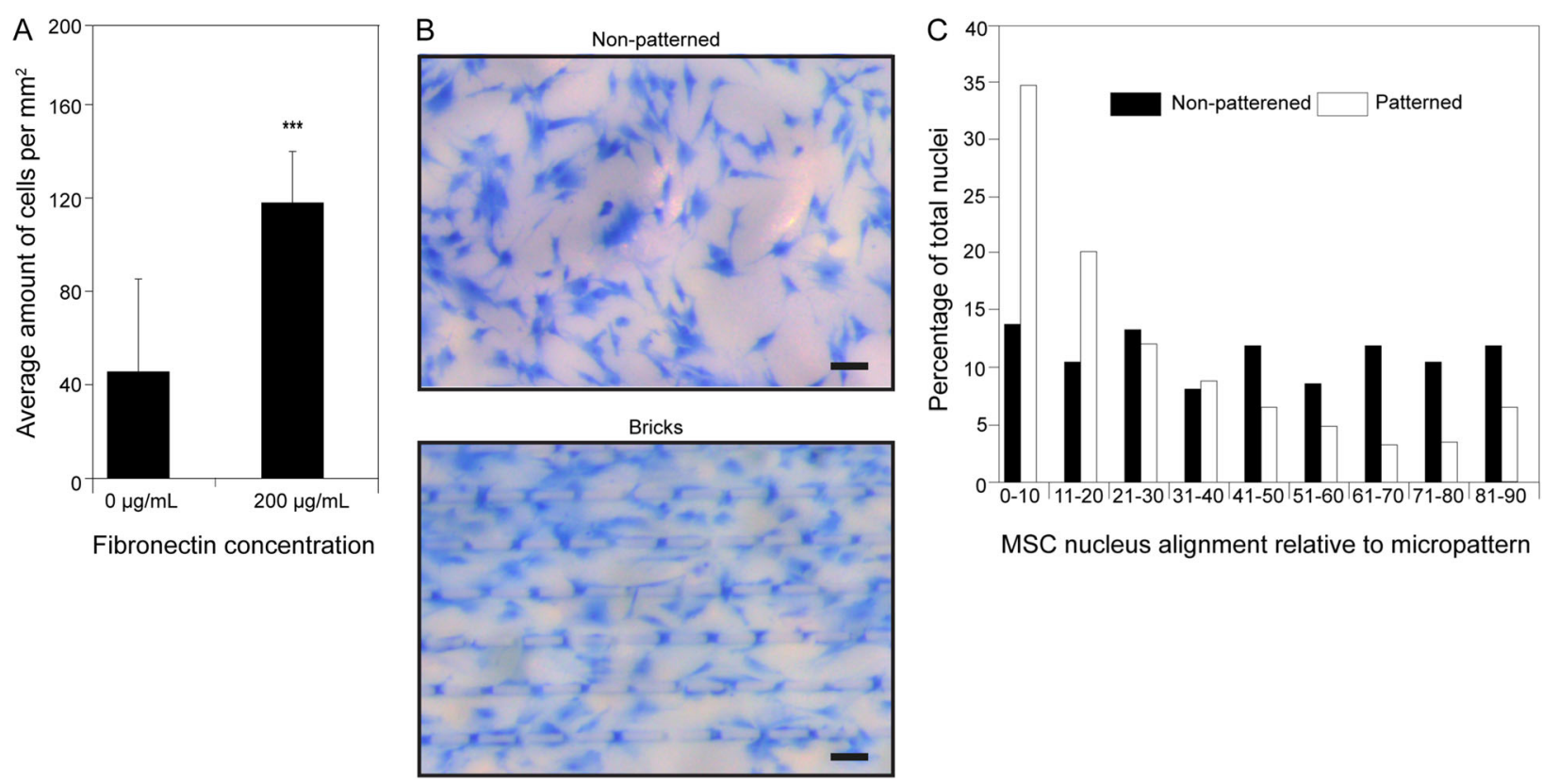

MSC nucleus alignment relative to micropattern

Fig. 2 a Attachment of MSCs to PES/PVP porous membranes, either uncoated $(0 \mu \mathrm{g} / \mathrm{mL})$ or coated with fibronectin $(200 \mu \mathrm{g} / \mathrm{mL})$. MSCs were seeded $\left(10.000\right.$ cells $\left./ \mathrm{cm}^{2}\right)$ on to the membranes coated with fibronectin and after 1 day of culture the total number of cells per $\mathrm{mm}^{2}$ was determined. b Methylene blue staining of MSCs on non-patterned and micropatterned membranes. c MSC nucleus alignment relative to micropatterns, where 0 degrees means that the nucleus was oriented parallel to the micropattern. Alignment to flat (black) and micropatterned (white) membranes was determined. Error $=$ SD. Scale bars $100 \mu \mathrm{m}$
A

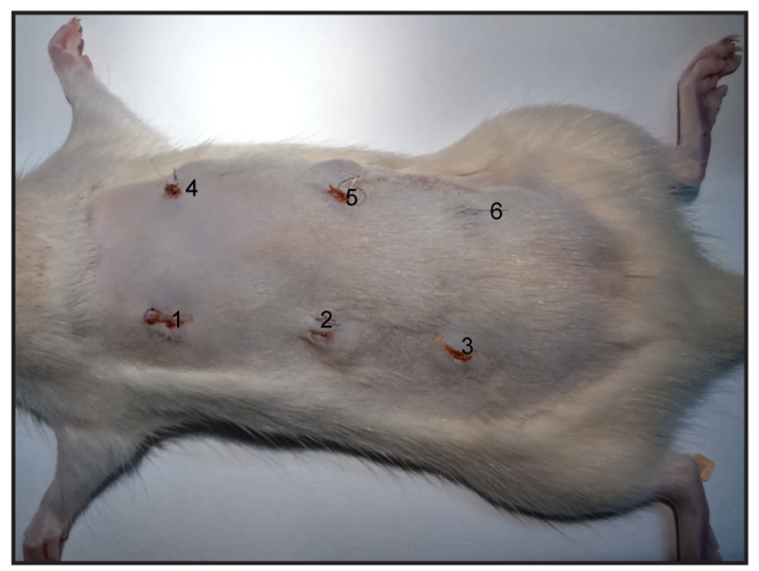

B

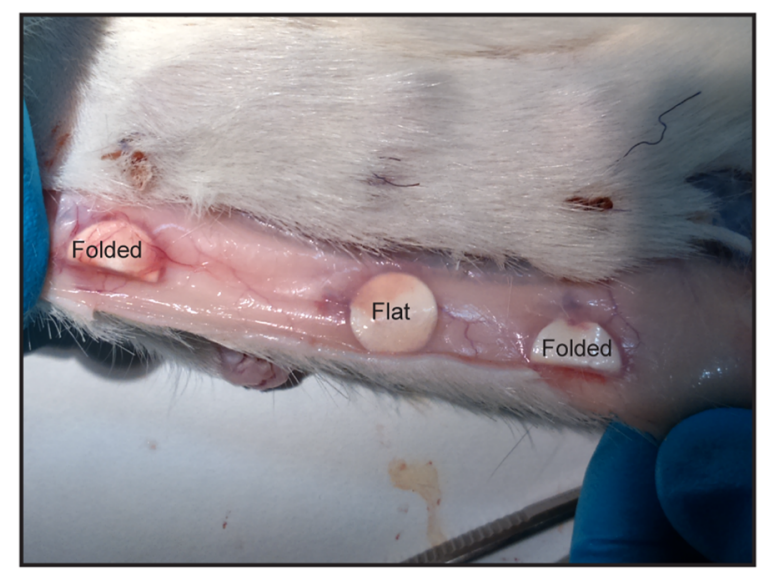

Fig. 3 a On the left, an example of the six implantation pockets at day 1, on the right $\mathbf{b}$ different configurations of the membranes upon explantation (Folded and Flat)

directions of the surface structures. Further analysis of cell nucleus confirmed that the micropatterned membranes induce MSC alignment in contrast to the non-patterned membranes where the MSCs have random orientation and cells are equally distributed in all directions (Fig. 2c).

\subsection{In vivo vascularization in female Lewis rats}

We also assessed the effect of MSCs cultured on patterned membranes on improving vessel formation in vivo.
Figure 3a shows the six pockets on the back of a rat (left) and different configurations upon explantation (right). After 14 days of implantation, the majority of the membranes (64\% of the samples) was explanted easily. Although the samples were implanted flat (Fig. 3b), some were found to be folded upon explantation. Besides, most of the samples that were flat during explantation had less tissue around them compared to the samples that were folded in vivo. Only $45 \%$ of the samples were still in a flat configuration upon explantation. Only $25 \%$ of these flat membranes were 
Fig. 4 In vivo vascularization in female Lewis rats. a examples of Trichrome stained sections of micropatterned membranes. The left (right) panel shows the samples without (with) MCSs cells. From each case, an typical example of each classification is depicted; - top, + middle, and ++ bottom. Examples of vessels are indicated with a red star. Scale bars $125 \mu \mathrm{m}$. b Analysis of vessel formation in vivo. The samples are classified in three categories; no vessels ( - black), some vessels $(+$ white), and lot of vessel infiltration $(++$ grey). The effect of non-patterned and micro-patterned membranes on vessel formation in samples without cells and in samples with MSCs. Error $=$ SD
A
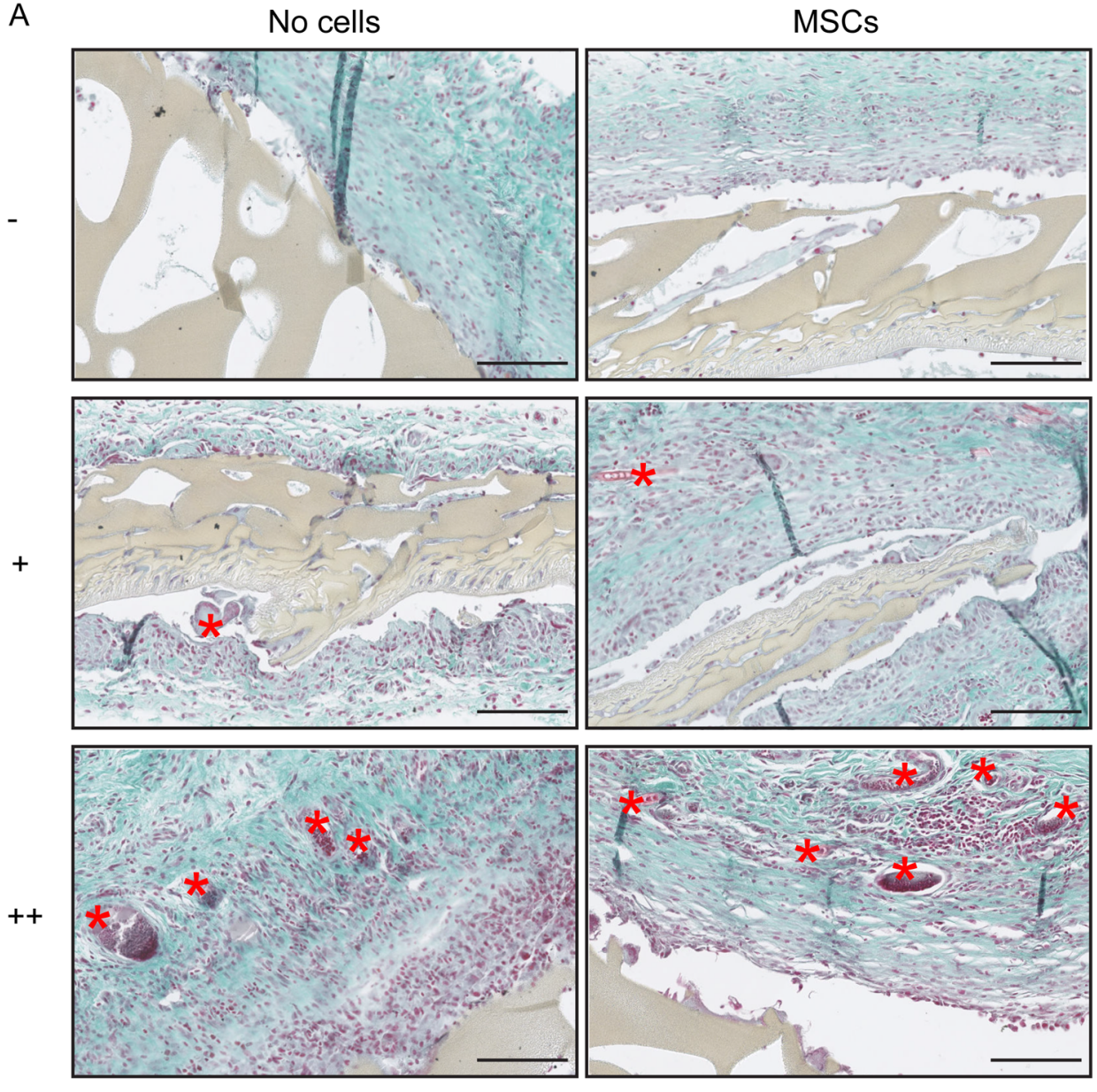

B

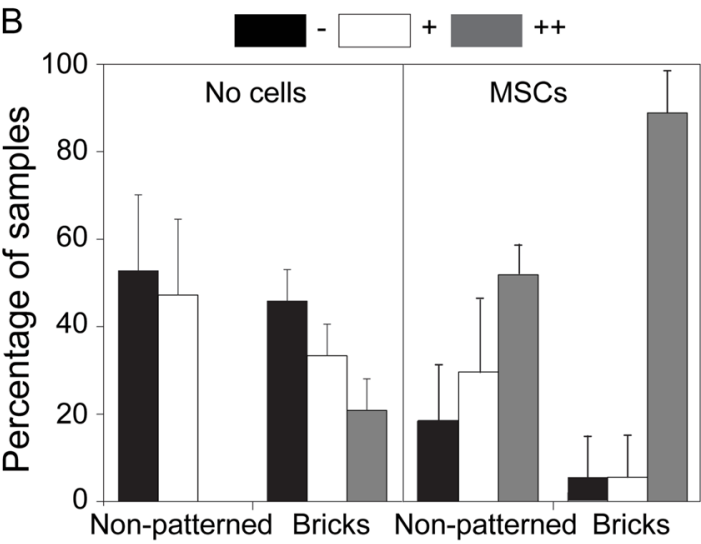

difficult to explant, whereas $45 \%$ of the folded samples were difficult to explant due to the presence of more dense tissue surrounding the implant.

A Masson-Goldner Trichrome staining was used to determine the vessel formation on day 14 for these samples. Vessel formation was independently scored by 3 blinded observers. In fact, the samples were categorized into three groups based on the vessel densities, ranging from samples with no vessels (-), samples with 1 to 2 vessels $(+)$, or samples with more than 3 vessels $(++)$. Figure 4a shows representative pictures of Trichrome stained sections with different vessel densities (from top till bottom) for samples without cells (left panel) and with MSCs (right panel) all with the micropatterned membranes (examples of vessels are indicated with a red star). Representative pictures of the non-patterned membranes are shown in supplementary figure 1 . The results of the vessel scoring of the staining are depicted in Fig. 4b. The left part of the graph shows very clearly that without cells, vascularization is increased when micropatterned membranes were used compared to non- 
patterned membranes. In approximately $20 \%$ of all sections with micropatterned membranes, more than 3 vessels (score: ++ ) were observed, whereas, none of the nonpatterned membranes were scored with ++ . The addition of MSCs to both membranes resulted in an increased vessel formation compared to these membranes without cells (right and left panel of the graph). In the case, $51 \%$ of the nonpatterned membranes which were cultured with MSCs had more than 3 vessels (score: ++ ). Interestingly, the highest vessel formation was observed for the samples where MSCs were cultured on the micropatterned membranes. In fact, $80 \%$ of these samples had more than 3 vessels (score: ++ ), clearly indicating that the culture of MSCs on the micropatterned membranes is necessary for achieving vessel formation in vivo.

\section{Discussion}

Survival of islets of Langerhans encapsulated in an immune-protective device is often hampered due to limited delivery of oxygen and nutrients to the cells as a result of lack of vascularization. After islet isolation and encapsulation, the pancreatic islets are separated from their native vasculature and have no direct access to the blood supply. Since the islets require high blood supply; in fact, although only $1 \%$ of the pancreas consists of islets, they receive 5$15 \%$ of the total blood supply to the pancreas $[6,27,28]$, it is important that one improves vascularization of the implant prior to implantation.

Many different strategies have been proposed to enhance vascularization of the implants; by using angiogenic factors, culture of MSCs or endothelial cells, or application of micropatterned scaffolds [26, 34, 36, 39-41]. In a previous study, we showed that a well-organized interconnected branched structure of HUVECs can be created on a layer of fibroblasts cultured on micropatterned membranes with brick like surface topography [48]. Those membranes can be used as a lid on an islet encapsulation device [47]. Here, we show for the first time that culture of MSCs on these micropatterned membranes can lead to formation of blood vessels around the membrane, in vivo.

The effect of micropatterned membranes and MSCs on vascularization was assessed by implanting PES/PVP membranes subcutaneously in female Lewis rats. Due to low cell adhesion on these membranes, fibronectin coating was applied there to enhance MSC attachment, following earlier coating protocols developed for the attachment of fibroblast cells on these membranes [48]. It is well known that MSCs attach well to fibronectin via RGD binding integrins, and more specifically $\alpha \mathrm{v}$-containing integrins [56-58]. Cell adhesion via integrins to ECM molecules, like fibronectin, activates intracellular signaling pathways that direct cell viability, proliferation and differentiation [59, 60]. Culture of MSCs with ECM molecules such as fibronectin can also improve cell proliferation [61]. Indeed, in our study, the fibronectin coating of the PES/PVP membranes, accelerated the attachment of MSCs significantly in the first $24 \mathrm{~h}$ after cell seeding.

In the in vivo study, membranes were coated with fibronectin as this was needed for MSCs attachment. As it is known that fibronectin may enhance vascularization by itself [62, 63], all samples were coated with fibronectin to make sure that observed difference between the nonpatterned and patterned membranes was not due to applied coating but due to introduced surface topography.

After 14 days of implantation the membranes cultured with MSCs had better vessel recruitment than the membranes implanted without cells, consistent with other studies [40, 64, 65]. Moreover, induction of vessel formation by MSCs has been shown to directly improve islet graft function [66, 67] and have immunomodulatory effects [68]. In fact, Figliuzzi et al. showed that only transplantation of 2000 islets in combination with MSCs resulted in normogliceamia in rat animal model [66].

In this study, we observed a significant increase in vessel formation around the micropatterned membranes. Actually, around $20 \%$ of the patterned samples were scored with 3 vessels or more whereas the non-patterned membrane had very low score. Other studies have shown that surface topographies are able to influence cell behavior, however, the effect is dependent on the dimensions and the specific morphology of the surface topographies applied [49, 69]. For example, Song et al showed that $10 \mu \mathrm{m}$ microposttextured PDMS scaffolds, combined with biochemical stimulus and MSCs, had a positive effect on vessel formation in vivo. However, their scaffolds with only surface topographies exhibited no vascularization [69]. In contrast, our membranes with brick like surface topography seem to induce some blood vessel formation without other stimuli, probaby due to the improve cell alignment and the ability of cell communication between the patterns. This was also clearly shown in our recent study of co-culturing HUVECs and fibroblasts on these micropatterned membranes [48]. There, the fibroblasts aligned very well and the HUVECs could span in between the patterns and create branch like cells networks.

A very important finding of this work is the additive effect of MSCs and surface topographies for achieving vessel formation. MSCs seeded on the micropatterned membranes with brick like surface topographies induced the highest vessel formation score $(++)$ in $80 \%$ of the samples. Other studies have also combined surface topographies with MSCs however, they were also combined with biological stimuli like VEGF and matrigel [70]. Our study is the first one which reports good vessel formation for the 
combination of micropatterned membranes with MSCs without the additional of other stimuli. We think that this is probably due to optimal brick like design which induces cell orientation and at the same time achieves good cell communication [48, 71].

\section{Conclusion and outlook}

Survival of islets of Langerhans encapsulated in an immune-protective device is often hampered due to limited delivery of oxygen and nutrients to the cells as a result of lack of vascularization. It is therefore highly important to induce vessel formation after transplantation. In this study, we investigated whether micropatterned membranes and MSC either separately or combined can improve vessel formation in vivo. Our results showed that we can achieve the best results (high vessel formation score $(++)$ in $80 \%$ of the samples) when combining MSCs cultured on brick like surface topographies.

In the future, we plan to perform implantation studies of our islet encapsulation device [47] with MSCs on a brick like patterned surface and investigate whether the islet viability and function can be maintained due to vessel formation around the device. Besides, since there are reports that the membrane surface topography and MSCs can also reduce the immune response to the implants [42-44, 72], we will systematically investigate the amount of positive macrophages and the chemotactic activity for inflammatory cells around our device.

Acknowledgements This research was supported by Juvenile Diabetes Research Institute Foundation Grant key: 17-2013-303 (http://jdrf.org/).

\section{Compliance with ethical standards}

Conflict of interest The authors declare that they have no conflict of interest.

Open Access This article is distributed under the terms of the Creative Commons Attribution 4.0 International License (http://crea tivecommons.org/licenses/by/4.0/), which permits use, duplication, adaptation, distribution, and reproduction in any medium or format, as long as you give appropriate credit to the original author(s) and the source, provide a link to the Creative Commons license, and indicate if changes were made.

\section{References}

1. Foulis AK. The pathology of the endocrine pancreas in type 1 (insulin-dependent) diabetes mellitus. APMIS. 1996;104:161-7.

2. Hornum L, Markholst $H$. New autoimmune genes and the pathogenesis of type 1 diabetes. Curr Diab Rep. 2004;4:135-42. https://doi.org/10.1007/s11892-004-0069-6.
3. Mathis $\mathrm{D}$, Vence $\mathrm{L}$, Benoist C. $\beta$-cell death during progression to diabetes. Nature. 2001;414:792-8. https://doi.org/10.1038/ 414792a.

4. Steele JAM, Hallé JP, Poncelet D, Neufeld RJ. Therapeutic cell encapsulation techniques and applications in diabetes. Adv Drug Deliv Rev. 2014;67-68:74-83. https://doi.org/10.1016/j.addr. 2013.09.015.

5. Van Belle TL, Coppieters KT, Von Herrath MG. Type 1 diabetes: etiology, immunology, and therapeutic strategies. Physiol Rev. 2011;91:79-118. https://doi.org/10.1152/physrev.00003.2010.

6. Ballian N, Brunicardi FC. Islet vasculature as a regulator of endocrine pancreas function. World J Surg. 2007;31:705-14. https://doi.org/10.1007/s00268-006-0719-8.

7. Beck J, Angus R, Madsen B, Britt D, Vernon B, Nguyen KT. Islet encapsulation: strategies to enhance islet cell functions. Tiss Eng. 2007;13:589-99. https://doi.org/10.1089/ten.2006.0183.

8. De Kort H, De Koning EJ, Rabelink TJ, Bruijn JA, Bajema IM. Islet transplantation in type 1 diabetes. BMJ. 2011;342:426-32. https://doi.org/10.1136/bmj.d217.

9. Kumar PCM. Diabetes mellitus and other disorders of metabolism. In: WB S, ed. Clinical Medicine 2002; p. 1069-210, London: Saunders.

10. Shapiro AMJ, Lakey JRT, Ryan EA, Korbutt GS, Toth E, Warnock GL, et al. Islet transplantation in seven patients with type 1 diabetes mellitus using a glucocorticoid-free immunosuppressive regimen. New Engl J Med. 2000;343:230-8. https://doi.org/10. 1056/NEJM200007273430401.

11. Shapiro AMJ, Ricordi C, Hering BJ, Auchincloss H, Lindblad R, Robertson RP, et al. International trial of the Edmonton protocol for islet transplantation. New Engl J Med. 2006;355:1318-30. https://doi.org/10.1056/NEJMoa061267.

12. Silva AI, Norton De Matos A, Brons IG, Mateus M. An overview on the development of a bio-artificial pancreas as a treatment of insulin-dependent diabetes mellitus. Med Res Rev. 2006;26:181222. https://doi.org/10.1002/med.20047.

13. Barshes NR, Wyllie S, Goss JA. Inflammation-mediated dysfunction and apoptosis in pancreatic islet transplantation: Implications for intrahepatic grafts. J Leukoc Biol. 2005;77:587-97. https://doi.org/10.1189/jlb.1104649.

14. Grundfest-Broniatowski SF, Tellioglu G, Rosenthal KS, Kang J, Erdodi G, Yalcin B, et al. A new bioartificial pancreas utilizing amphiphilic membranes for the immunoisolation of porcine islets a pilot study in the canine. ASAIO J. 2009;55:400-5. https://doi. org/10.1097/MAT.0b013e3181a8deba.

15. Kort HD, Koning EJD, Rabelink TJ, Bruijn Ja, Bajema IM. Islet transplantation in type 1 diabetes. BMJ. 2011;342(jan21 1):d217d. https://doi.org/10.1136/bmj.d217.

16. Özmen L, Ekdahl KN, Elgue G, Larsson R, Korsgren O, Nilsson B. Inhibition of thrombin abrogates the instant blood-mediated inflammatory reaction triggered by isolated human islets: possible application of the thrombin inhibitor Melagatran in clinical islet transplantation. Diabetes. 2002;51:1779-84. https://doi.org/10. 2337/diabetes.51.6.1779.

17. Nanji SA, Shapiro AMJ. Advances in pancreatic islet transplantation in humans. Diabetes Obes Metab. 2006;8:15-25. https://doi. org/10.1111/j.1463-1326.2005.00476.x.

18. Moberg L, Johansson H, Lukinius A, Berne C, Foss A, Källen R, et al. Production of tissue factor by pancreatic islet cells as a trigger of detrimental thrombotic reactions in clinical islet transplantation. Lancet. 2002;360:2039-45. https://doi.org/10.1016/ S0140-6736(02)12020-4.

19. Citro A, Cantarelli E, Piemonti L. Anti-inflammatory strategies to enhance islet engraftment and survival. Curr Diab Rep. 2013;13:733-44. https://doi.org/10.1007/s11892-013-0401-0. 
20. Harlan DM, Kenyon NS, Korsgren O, Roep BO. Current advances and travails in islet transplantation. Diabetes. 2009;58:217584. https://doi.org/10.2337/db09-0476.

21. Azzi J, Geara AS, El-Sayegh S, Abdi R. Immunological aspects of pancreatic islet cell transplantation. Expert Rev Clin Immunol. 2010;6:111-24. https://doi.org/10.1586/eci.09.67.

22. Silva AI, de Matos AN, Brons IG, Mateus M. An overview on the development of a bio-artificial pancreas as a treatment of insulindependent diabetes mellitus. Med Res Rev. 2006;26:181-222. https://doi.org/10.1002/med.20047.

23. Silva AI, Mateus M. Development of a polysulfone hollow fiber vascular bio-artificial pancreas device for in vitro studies. J Biotechnol. 2009;139:236-49. https://doi.org/10.1016/j.jbiotec.2008. 12.004 .

24. Lacy PE, Hegre OD, Gerasimidi-vazeou A, Gentile FT, Dionne E, Science $S$, et al. Maintenance of normoglycemia in diabetic mice by subcutaneous xenografts of encapsulated islets. Science. 1991;254:1782-4.

25. Risbud MV, Bhonde RR. Islet immunoisolation: experience with biopolymers. J Biomater Sci Polym Ed. 2001;12:1243-52. https:// doi.org/10.1163/156856201753395770.

26. Colton CK. Oxygen supply to encapsulated therapeutic cells. Adv Drug Deliv Rev. 2014;67-68:93-110. https://doi.org/10.1016/j. addr.2014.02.007.

27. Homo-Delarche F, Boitard C. Autoimmune diabetes: the role of the islets of Langerhans. Immunol Today. 1996;17:456-60. https://doi.org/10.1016/0167-5699(96)10053-8.

28. Trivedi N, Steil GM, Colton CK, Bonner-Weir S, Weir GC. Improved vascularization of planar membrane diffusion devices following continuous infusion of vascular endothelial growth factor. Cell Transplant. 2000;9:115-24. https://doi.org/10.1177/ 096368970000900114.

29. Daoud J, Petropavlovskaia M, Rosenberg L, Tabrizian M. The effect of extracellular matrix components on the preservation of human islet function in vitro. Biomaterials. 2010;31:1676-82. https://doi.org/10.1016/j.biomaterials.2009.11.057.

30. Kanak MA, Takita M, Kunnathodi F, Lawrence MC, Levy MF, Naziruddin B. Inflammatory response in islet transplantation. Int $\mathbf{J}$ Endocrinol. 2014;2014:451035. https://doi.org/10.1155/2014/ 451035.

31. Bloch K, Papismedov E, Yavriyants K, Vorobeychik M, Beer S, Vardi P. Photosynthetic oxygen generator for bioartificial pancreas. Tiss Eng. 2006;12:337-44. https://doi.org/10.1089/ten. 2006.12.337.

32. Brauker JH, Carr-Brendel VE, Martinson LA, Crudele J, Johnston WD, Johnson RC. Neovascularization of synthetic membranes directed by membrane microarchitecture. J Biomed Mater Res. 1995;29:1517-24. https://doi.org/10.1002/jbm.820291208.

33. Auger FA, Gibot L, Lacroix D. The pivotal role of vascularization in tissue engineering. Ann Rev Biomed Eng. 2013;15:177-200.

34. Borg DJ, Bonifacio E. The use of biomaterials in islet transplantation. Curr Diab Rep. 2011;11:434-44. https://doi.org/10.1007/ s11892-011-0210-2.

35. Deters NA, Stokes RA, Gunton JE. Islet transplantation: factors in short-term islet survival. Arch Immunol Ther Exp (Warsz). 2011;59:421-9. https://doi.org/10.1007/s00005-011-0143-0.

36. Kang S, Park HS, Jo A, Hong SH, Lee HN, Lee YY, et al. Endothelial progenitor cell cotransplantation enhances islet engraftment by rapid revascularization. Diabetes. 2012;61:86676. https://doi.org/10.2337/db10-1492.

37. Penko D, Rojas-Canales D, Mohanasundaram D, Peiris HS, Sun WY, Drogemuller CJ, et al. Endothelial progenitor cells enhance islet engraftment, influence $\beta$-cell function, and modulate islet connexin 36 expression. Cell Transplant. 2015;24:37-48. https:// doi.org/10.3727/096368913X673423.
38. Teramura Y, Iwata H. Bioartificial pancreas. Microencapsulation and conformal coating of islet of Langerhans. Adv Drug Deliv Rev. 2010;62:827-40. https://doi.org/10.1016/j.addr.2010.01.005.

39. Vériter S, Aouassar N, Adnet PY, Paridaens MS, Stuckman C, Jordan B, et al. The impact of hyperglycemia and the presence of encapsulated islets on oxygenation within a bioartificial pancreas in the presence of mesenchymal stem cells in a diabetic Wistar rat model. Biomaterials. 2011;32:5945-56. https://doi.org/10.1016/j. biomaterials.2011.02.061.

40. Vériter S, Gianello P, Igarashi Y, Beaurin G, Ghyselinck A, Aouassar $\mathrm{N}$, et al. Improvement of subcutaneous bioartificial pancreas vascularization and function by coencapsulation of pig islets and mesenchymal stem cells in primates. Cell Transplant. 2014;23:1349-64. https://doi.org/10.3727/096368913X663550.

41. Wang X, Meloche M, Verchere CB, Ou D, Mui A, Warnock GL. Improving islet engraftment by gene therapy. J Transplant. 2011;2011:7 https://doi.org/10.1155/2011/594851.

42. Brusko TM. Mesenchymal stem cells: a potential border patrol for transplanted islets? Diabetes. 2009;58:1728-9. https://doi.org/10. 2337/db09-0749.

43. Ding Y, Bushell A, Wood KJ. Mesenchymal stem-cell immunosuppressive capabilities: therapeutic implications in islet transplantation. Transplantation. 2010;89:270-3. https://doi.org/10. 1097/TP.0b013e3181c6ffbe.

44. Ding Y, Xu D, Feng G, Bushell A, Muschel RJ, Wood KJ. Mesenchymal stem cells prevent the rejection of fully allogenic islet grafts by the immunosuppressive activity of matrix metalloproteinase-2 and -9. Diabetes. 2009;58:1797-806. https:// doi.org/10.2337/db09-0317.

45. Jiang XX, Zhang Y, Liu B, Zhang SX, Wu Y, Yu XD, et al. Human mesenchymal stem cells inhibit differentiation and function of monocyte-derived dendritic cells. Blood. 2005;105:41206. https://doi.org/10.1182/blood-2004-02-0586.

46. Spaggiari GM, Capobianco A, Becchetti S, Mingari MC, Moretta L. Mesenchymal stem cell-natural killer cell interactions: evidence that activated NK cells are capable of killing MSCs, whereas MSCs can inhibit IL-2-induced NK-cell proliferation. Blood. 2006;107:1484-90. https://doi.org/10.1182/blood-2005-07-2775.

47. Skrzypek K, Groot Nibbelink M, Van Lente J, Buitinga M, Engelse MA, De Koning EJP, et al. Pancreatic islet macroencapsulation using microwell porous membranes. Sci Rep. 2017;7. https://doi.org/10.1038/s41598-017-09647-7.

48. Skrzypek K, Nibbelink MG, Karbaat LP, Karperien M, van Apeldoorn A, Stamatialis D. An important step towards a prevascularized islet macroencapsulation device-effect of micropatterned membranes on development of endothelial cell network. J Mater Science. 2018;29. https://doi.org/10.1007/s10856-0186102-0.

49. Krishnan L, Chang CC, Nunes SS, Williams SK, Weiss JA, Hoying JB. Manipulating the microvasculature and its microenvironment. Crit Rev Biomed Eng. 2013;41:91-123. https://doi. org/10.1615/CritRevBiomedEng.2013008077.

50. Anderson DEJ, Hinds MT. Endothelial cell micropatterning: methods, effects, and applications. Ann Biomed Eng. 2011;39:2329-45. https://doi.org/10.1007/s10439-011-0352-z.

51. Aubin H, Nichol JW, Hutson CB, Bae H, Sieminski AL, Cropek $\mathrm{DM}$, et al. Directed 3D cell alignment and elongation in microengineered hydrogels. Biomaterials. 2010;31:6941-51. https://doi. org/10.1016/j.biomaterials.2010.05.056.

52. Duncan AC, Rouais F, Lazare S, Bordenave L, Baquey C. Effect of laser modified surface microtopochemistry on endothelial cell growth. Colloids Surf B. 2007;54:150-9. https://doi.org/10.1016/ j.colsurfb.2006.09.013.

53. Stamatialis DF, Papenburg BJ, Gironés M, Saiful S, Bettahalli SNM, Schmitmeier S, et al. Medical applications of membranes: drug delivery, artificial organs and tissue engineering. J Memb 
Sci. 2008;308:1-34. https://doi.org/10.1016/j.memsci.2007.09. 059.

54. Clark RA, Folkvord JM, Nielsen LD. Either exogenous or endogenous fibronectin can promote adherence of human endothelial cells. J Cell Sci. 1986;82:263-80.

55. Heilshorn SC, DiZio KA, Welsh ER, Tirrell DA. Endothelial cell adhesion to the fibronectin CS5 domain in artificial extracellular matrix proteins. Biomaterials. 2003;24:4245-52. https://doi.org/ 10.1016/S0142-9612(03)00294-1.

56. Kilpadi KL, Sawyer AA, Prince CW, Chang PL, Bellis SL. Primary human marrow stromal cells and Saos- 2 osteosarcoma cells use different mechanisms to adhere to hydroxylapatite. J Biomed Mater Res. 2004;68:273-85.

57. Vohra S, Hennessy KM, Sawyer AA, Zhuo Y, Bellis SL. Comparison of mesenchymal stem cell and osteosarcoma cell adhesion to hydroxyapatite. J Mater Sci: Mater Med. 2008;19:3567-74. https://doi.org/10.1007/s10856-008-3525-z.

58. Zwolanek D, Flicker M, Kirstatter E, Zaucke F, van Osch GJ, Erben RG. beta1 Integrins mediate attachment of mesenchymal stem cells to cartilage lesions. Biores Open Access. 2015;4:39-53. https://doi.org/10.1089/biores.2014.0055.

59. Giancotti FG, Ruoslahti E. Integrin signaling. Science. 1999;285:1028-32. https://doi.org/10.1126/science.285.5430. 1028.

60. Hynes RO. Integrins: bidirectional, allosteric signaling machines. Cell. 2002;110:673-87. https://doi.org/10.1016/S0092-8674(02) 00971-6.

61. Lindner U, Kramer J, Behrends J, Driller B, Wendler NO, Boehrnsen $\mathrm{F}$, et al. Improved proliferation and differentiation capacity of human mesenchymal stromal cells cultured with basement-membrane extracellular matrix proteins. Cytotherapy. 2010;12:992-1005. https://doi.org/10.3109/14653249.2010. 510503.

62. Rosso F, Marino G, Giordano A, Barbarisi M, Parmeggiani D, Barbarisi A. Smart materials as scaffolds for tissue engineering. J Cell Physiol. 2005;203:465-70. https://doi.org/10.1002/jcp. 20270.

63. van Obberghen-Schilling E, Tucker RP, Saupe F, Gasser I, Cseh B, Orend G. Fibronectin and tenascin-C: accomplices in vascular morphogenesis during development and tumor growth. Int J Dev Biol. 2011;55:511-25. https://doi.org/10.1387/ijdb.103243eo.
64. Tang YL, Zhao Q, Zhang YC, Cheng L, Liu M, Shi J, et al. Autologous mesenchymal stem cell transplantation induce VEGF and neovascularization in ischemic myocardium. Regul Pept. 2004;117:3-10. https://doi.org/10.1016/j.regpep.2003.09.005.

65. Buitinga M, Janeczek Portalska K, Cornelissen DJ, Plass J, Hanegraaf M, Carlotti F, et al. Coculturing human islets with proangiogenic support cells to improve islet revascularization at the subcutaneous transplantation site. Tissue Eng. 2016;22:37585. https://doi.org/10.1089/ten.tea.2015.0317.

66. Figliuzzi M, Cornolti R, Perico N, Rota C, Morigi M, Remuzzi G, et al. Bone marrow-derived mesenchymal stem cells improve islet graft function in diabetic rats. Transplant Proc. 2009;41:1797800. https://doi.org/10.1016/j.transproceed.2008.11.015.

67. Ito T, Itakura S, Todorov I, Rawson J, Asari S, Shintaku J, et al. Mesenchymal stem cell and islet co-transplantation promotes graft revascularization and function. Transplantation. 2010;89:143845. https://doi.org/10.1097/TP.0b013e3181db09c4.

68. Longoni B, Szilagyi E, Quaranta P, Paoli GT, Tripodi S, Urbani S, et al. Mesenchymal stem cells prevent acute rejection and prolong graft function in pancreatic islet transplantation. Diabetes Technol. 2010;12:435-46. https://doi.org/10.1089/dia.2009.0154.

69. Song S, Kim EJ, Bahney CS, Miclau T, Marcucio R, Roy S. The synergistic effect of micro-topography and biochemical culture environment to promote angiogenesis and osteogenic differentiation of human mesenchymal stem cells. Acta Biomater. 2015;18:100-11. https://doi.org/10.1016/j.actbio.2015.02.021.

70. Kukumberg M, Yao JY, Neo DJH, Yim EKF. Microlens topography combined with vascular endothelial growth factor induces endothelial differentiation of human mesenchymal stem cells into vasculogenic progenitors. Biomaterials. 2017;131:68-85. https:// doi.org/10.1016/j.biomaterials.2017.03.036.

71. Papenburg BJ, Vogelaar L, Bolhuis-Versteeg LAM, Lammertink RGH, Stamatialis D, Wessling M. One-step fabrication of porous micropatterned scaffolds to control cell behavior. Biomaterials. 2007;28:1998-2009. https://doi.org/10.1016/j.biomaterials.2006. 12.023 .

72. Karazisis D, Petronis S, Agheli H, Emanuelsson L, Norlindh B, Johansson A, et al. The influence of controlled surface nanotopography on the early biological events of osseointegration. Acta Biomater. 2017;53:559-71. https://doi.org/10.1016/j.actbio.2017. 02.026 .

\section{Affiliations}

\section{Milou Groot Nibbelink ${ }^{1} \cdot$ Katarzyna Skrzypek ${ }^{2} \cdot$ Lisanne Karbaat $^{2} \cdot$ Sanne Both $^{1} \cdot$ Jacqueline Plass $^{1}$. Bettie Klomphaar $^{3} \cdot$ Jéré van Lente $^{1} \cdot$ Sieger Henke ${ }^{1} \cdot$ Marcel Karperien $^{1} \cdot$ Dimitrios Stamatialis $^{2}$. Aart van Apeldoorn ${ }^{1,4,4}$}

1 Developmental BioEngineering, MIRA Institute of Biomedical Technology and Technical Medicine, University of Twente, Maastricht, The Netherlands

2 (Bio)artificial organs. Department of Biomaterials Science and Technology, MIRA Institute of Biomedical Technology and Technical Medicine University of Twente, Maastricht, The Netherlands
3 Biomedical Signals and Systems, MIRA Institute of Biomedical Technology and Technical Medicine, University of Twente, Maastricht, The Netherlands

4 Complex Tissue Regeneration, MERLN Institute for Technology Inspired Regenerative Medicine, Maastricht University, Maastricht, The Netherlands 